\title{
A geophysical survey of the De Gerlache Seamounts: preliminary results
}

Received: 13 February 1997 / Revision received: 30 September 1997

\begin{abstract}
The De Gerlache Seamounts actually consist of two medium-sized guyots, with summits at depths of 350-600 m. Acoustic profiler data show no significant sediment on these guyots. Alkaline basalts dredged from the summit of the eastern guyot yield $\mathrm{K} / \mathrm{Ar}$ ages between $20.1 \pm 1.0$ and $23.2 \pm 1.2 \mathrm{Ma}$. Basement ridges and sediment-filled troughs between the guyots are associated with the prominent gravity anomaly extending north from the Antarctic margin. This structure possibly played a role in the guyot formation, however, the question of how the De Gerlache Seamounts are related to this gravity anomaly remains uncertain.
\end{abstract}

\section{Introduction}

The De Gerlache Seamounts are located in the southeast Pacific between $64^{\circ} 30^{\prime}$ and $66^{\circ} \mathrm{S}$ and $90^{\circ}$ and $94^{\circ} \mathrm{W}$ (Fig. 1). This is a remote area that is little explored. Only a few shiptracks existed in the area, and the number, shapes, and true locations of these seamounts were poorly known prior to our survey.

The De Gerlache Seamounts appear to have been first discovered by the US Navy ship Eltanin, which conducted several surveys in the southeast Pacific in the 1960s and

\section{Rick A. Hagen $(\varangle)$}

Naval Research Laboratory, Code 7420, 4555 Overlook Ave. SW, Washington, DC 20375, USA

Karsten Gohl

School of Earth Sciences, Macquarie University, Sydney, New South Wales, 2109 Australia

Rainer Gersonde · Gehard Kuhn

Alfred Wegener Institute for Polar and Marine Research, Postfach 120161, 27515 Bremerhaven, Germany

David Völker

Fachbereich Geowissenschaften, University of Bremen, 28359 Bremen, Germany

V. N. Kodagali

National Institute of Oceanography, Dona Paula, Goa, India 1970s. The eastern seamount was crossed twice during Eltanin cruise 42 in 1970 and was recognized as a guyot. The shallowest depth recorded at that time was $391 \mathrm{~m}$ (Tucholke and Houtz 1976).

The most recent visitor to the De Gerlache Seamounts, prior to the cruise reported here, was the $R / V$ James Clark Ross, which crossed both seamounts, collecting multichannel seismic and other geophysical data in 1993 (P. Barker, personal communication, 1995).

In March and April 1995, the German polar research vessel Polarstern spent 53 days conducting geophysical surveys in the SE Pacific between $50^{\circ}$ and $70^{\circ} \mathrm{S}$ and between $70^{\circ}$ and $100^{\circ} \mathrm{W}$. During this expedition (ANTXII/4), several days were devoted to geological and geophysical studies over the De Gerlache Seamounts (Fig. 2). Data collected during these surveys consists of over $1000 \mathrm{~km}$ of underway geophysical data (multibeam bathymetry, echosounder, and gravity data), $220 \mathrm{~km}$ of multichannel seismic reflection data, four sediment cores, and one dredge.

The Polarstern is equipped with a Hydrosweep DS multibeam echosounding system, a Parasound penetrating echosounder, and a gravimeter, all of which were operated continuously. Also collected in selected areas were 96-channel seismic reflection data. Unfortunately, because of frequent stops for station work, a magnetometer was rarely deployed during this cruise.

The Hydrosweep multibeam system on the Polarstern provides swath bathymetry and side-scan sonar data from a swath of sea floor with a width equal to 2 times the water depth in the deep-sea (Grant and Schreiber 1990). At shallower depths $(<2500 \mathrm{~m})$ the total opening angle of the system can be increased to $120^{\circ}$, providing a data swath of approximately 3.4 times the water depth.

The Parasound penetrating echosounder is a narrowbeam system that generates signals at two frequencies (Grant and Schreiber 1990). The use of this parametric effect, which results from nonlinear interaction of high-amplitude signals, allows the emission of acoustic 
Fig. 1 Location of the De Gerlache Seamounts. The area enclosed in the box is the study area of this paper. The base map is shaded-relief satellite-derived gravity data, illuminated from the northeast (Smith and Sandwell 1994)

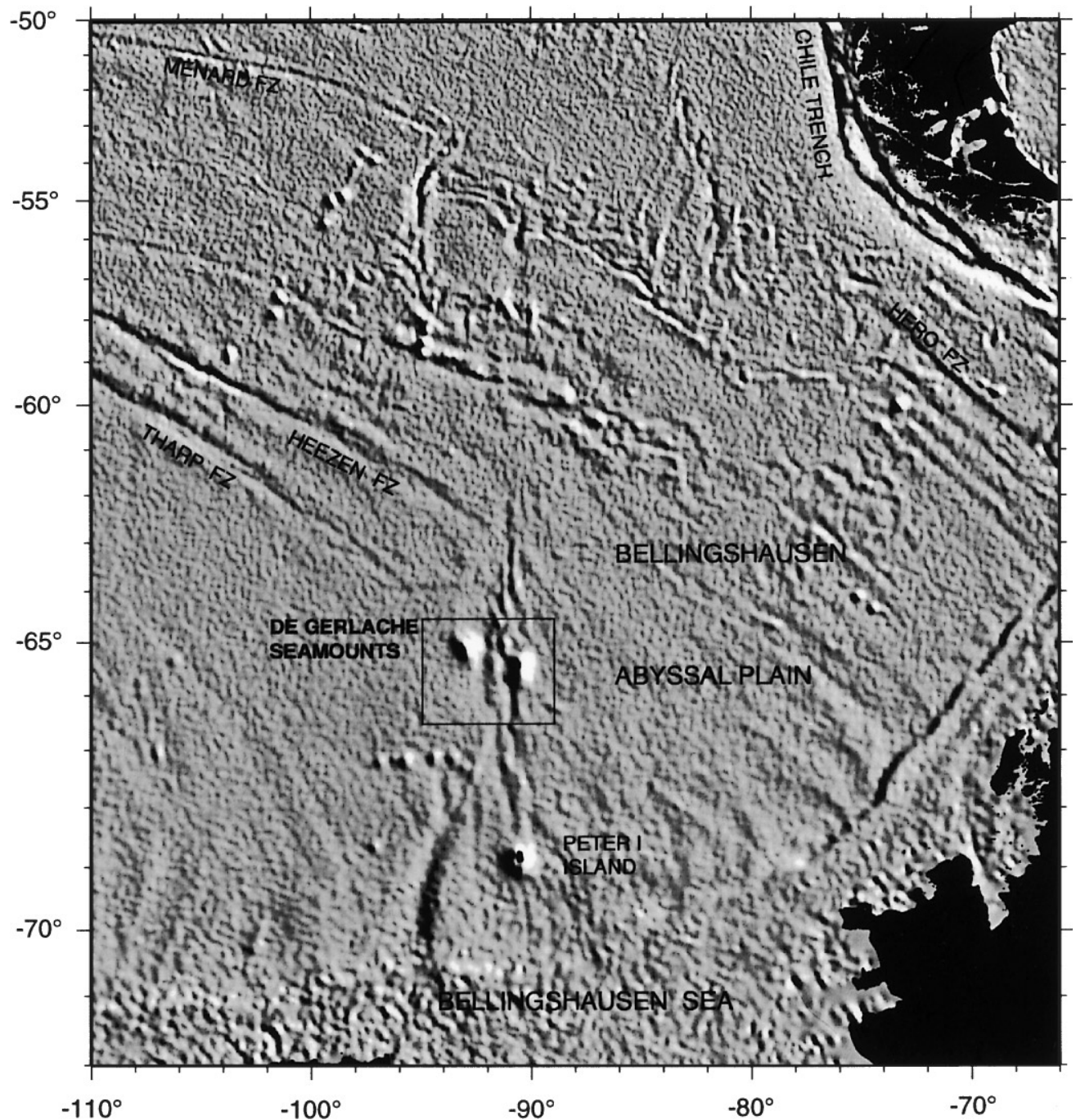

energy at $2.5-5.5 \mathrm{kHz}$ in a narrow (about $4^{\circ}$ ) beam. Side echoes are virtually eliminated, and both vertical and lateral resolution are increased significantly. The diameter of the footprint area is only about $7 \%$ of the water depth compared to $>30 \%$ for conventional $3.5-\mathrm{kHz}$ systems. A digital data acquisition system (ParaDigMa) is used on board the Polarstern to collect these ultra-high-resolution seismic data and make them available for later quantitative geophysical analyses.

A $220-\mathrm{km}$ multichannel seismic reflection profile was also shot across both of the De Gerlache Seamounts (Fig. 2) to investigate the basement structure of the guyot flanks and the basin between the guyots. Seismic signals generated by an array of 8 airguns, with a total volume of 24 liters, were recorded by a 96-channel streamer with a 2400-m active length. The seismic data were processed in conventional steps, with particular care given to velocity analyses. However, the steep flanks of the guyots and the hard surface of their flat tops caused difficulties in data processing. Seabottom multiples could not be completely removed and obscure the image beneath the guyots.

\section{New Data}

\section{Bathymetry}

Underway geophysical surveys in the De Gerlache Seamounts area were concentrated on the eastern guyot, which has been named Belgica Guyot (Fig. 2). Bathymetric coverage of Belgica Guyot is approximately $50 \%$. Because the swath coverage of the multibeam bathymetry system is depth dependent, coverage is better on the flanks of the guyot than on its shallow, flat summit. However, the distribution of our data is good and gaps in the bathymetric data are easily interpolated, allowing us to produce an accurate map of the guyot (Fig. 3). Belgica Guyot is elongated in shape, approximately $60 \mathrm{~km} \mathrm{E}-\mathrm{W}$ 


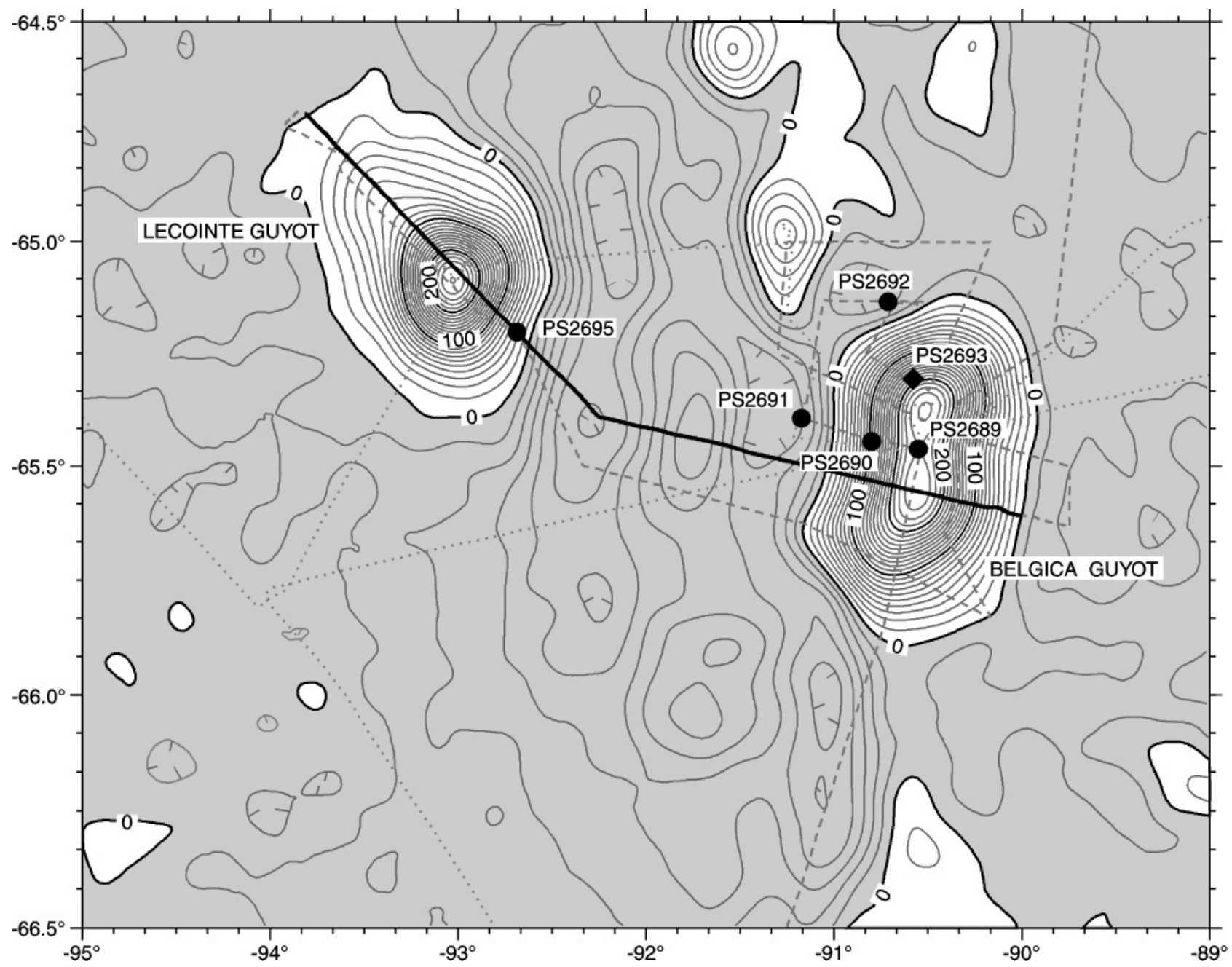

Fig. 2 Shiptracks showing locations of data used in this study overlain on GEOSAT/SEASAT satellite-derived gravity data (Smith and Sandwell 1994). Negative gravity values are shaded gray and positive values are white. Contour interval is $10 \mathrm{mgal}$. The thick black trackline indicates the location of the multichannel seismic profile. Core locations are indicated by black circles. The single dredge location is indicated by the black diamond

and $90 \mathrm{~km} \mathrm{~N}-\mathrm{S}$ at its base, and $17 \times 46 \mathrm{~km}$ at its summit. The summit area is a gently domed plain, lying at depths of $390-600 \mathrm{~m}$. The area of the summit plateau of this guyot is about $600 \mathrm{~km}^{2}$, making it an average-sized Pacific guyot (Vogt and Smoot 1984).

Our coverage of the western guyot (Lecointe Guyot) is much poorer, consisting of two closely spaced parallel tracks (Fig. 2). Single-beam bathymetric data from the 1993 cruise of the James Clark Ross (P. Barker, personal communication, 1995) were also used in this area. Although these combined data are not sufficient to enable us to produce an accurate bathymetric map of Lecointe Guyot, they allow us to infer the general morphology with some confidence (Fig. 3). Like Belgica Guyot, it is approximately $90 \times 60 \mathrm{~km}$ at its base. The summit, however, is more circular and is about $17 \mathrm{~km}$ in diameter. The summit of Lecointe Guyot is also a gently domed plain, about $200 \mathrm{~km}^{2}$, lying at depths of between 350 and $500 \mathrm{~m}$. Both guyots have average slopes on their flanks of about $11^{\circ}$, near the mean for Pacific guyots (Vogt and Smoot 1984). On the northwest flank of Lecointe Guyot, a very rugged shelf occurs between 2000 and $3000 \mathrm{~m}$ depth. This shelf is about $15 \mathrm{~km}$ wide and consists of several ridges and peaks with relief of up to $800 \mathrm{~m}$.

Throughout these surveys we found the locations, areal extent, and morphologies of the sea-floor features measured by the Hydrosweep multibeam system to agree closely with the satellite-derived gravity data (Smith and Sandwell 1994) that was used for cruise planning (Figs. 1 and 2). This close correlation between the gravity data and bathymetric data gives us confidence in interpolating gaps in our data, and in extending our interpretations to unsurveyed areas.

In general, we found preexisting bathymetric data in this area to be so sparse and so inaccurate, because of poor navigation (presatellite), as to be nearly useless for inclusion in our bathymetric maps. Both of the guyots were found to be incorrectly located on the current 


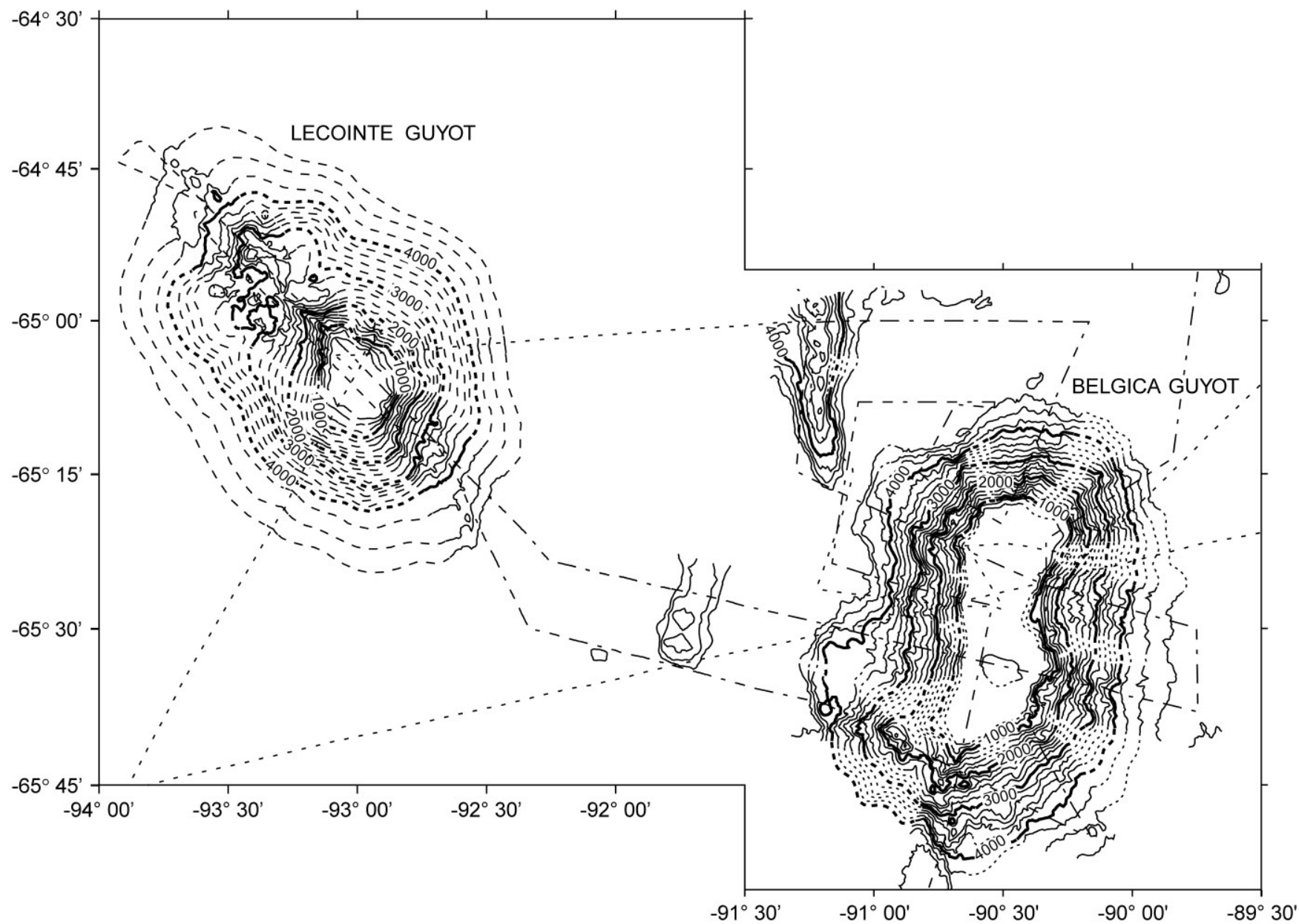

Fig. 3 Bathymetric map of the De Gerlache Seamounts. Contour interval is $200 \mathrm{~m}$. Shiptracks of the Polarstern Hydrosweep multibeam survey are shown as dotted-dashed lines. Shiptracks of singlebeam data from the James Clark Ross are shown by short dashed lines. Data from earlier cruises, collected prior to satellite navigation, were not included because of obvious positional errors. Dashed contours are interpolated. Contouring was guided by satellite-derived gravity data in areas of poor bathymetric coverage

GEBCO charts of this area (Mammerickx and Cande 1982), and both were found to be much shallower than indicated. In addition, the shape of the well-surveyed Belgica Guyot is strikingly different from that shown on the GEBCO chart.

\section{Seismic data}

Seismic profile AWI-95210 (Fig. 4) is a cross-section of the guyots, their flanks, and the intermediate basin. The seismic image beneath the guyot tops is largely diffuse and unstructured. There is no evidence for sedimentary sequences beneath the flat tops; the large-amplitude seismic multiples suggest exposed basement. A few small sediment-filled ponds are found across the deeper parts of the guyot flanks. A rough, exposed basement topography occurs on the NW flank of Lecointe Guyot.

Between the two guyots, the seismic profile crosses two sediment-filled troughs, separated by an exposed basement block (Fig. 4). The eastern trough is $17 \mathrm{~km}$ wide and about $1.3 \mathrm{~km}$ deep, whereas the western trough has a width of $37 \mathrm{~km}$ and a maximum sedimentary thickness of about $700 \mathrm{~m}$. The sedimentary sequences are well stratified and horizontally layered, with only the lower units inclining upward to the basement flanks. No major faults or discontinuities disrupt the sequences. The basement beneath the troughs does not display any correlable seismic reflections and is acoustically homogeneous. Moho reflections are not observed.

\section{Parasound echosounder data}

Parasound data across the summits of the guyots reveal a rough microtopography, extremely high reflection amplitudes, and no significant signal penetration, suggesting that volcanic basement is exposed at the surface. Data from the deep-sea basin surrounding the guyots show densely spaced, parallel reflectors up to a maximum signal penetration depth of $50 \mathrm{~m}$. In some areas these reflectors 


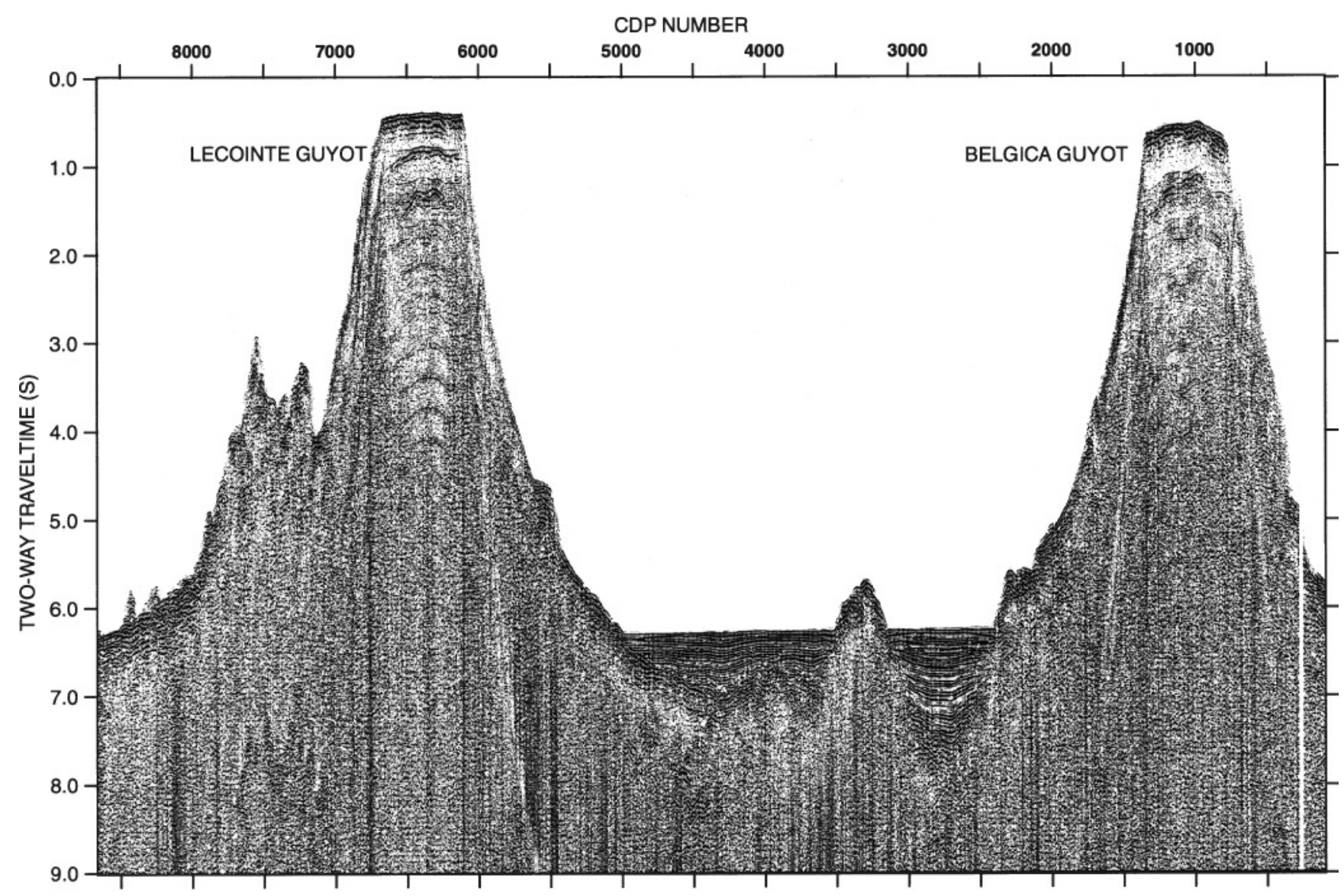

Fig. 4 Multichannel seismic profile across the De Gerlache Seamounts. Two sedimentary troughs of about 700 and $1300 \mathrm{~m}$ thickness are separated by exposed basement. The gravity field derived from satellite altimetry data indicates that this uplifted basement block is part of a ridge striking $\mathrm{N}-\mathrm{S}$. Vertical exaggeration is about 20

grade into a single, prolonged bottom echo. This is probably the result of current winnowing. Stronger bottom currents near the bases of the guyots remove fine sediment particles, resulting in a sea floor covered by coarse substrate and giving rise to a single prolonged reflector.

Erosional moats were found at the base of Belgica Guyot on the northern and western flanks, but not on the eastern and southern flanks. The moats have a maximum width of $1.5 \mathrm{~km}$ and a maximum depth of $30 \mathrm{~m}$. They are often accompanied by elongate mounds seaward of the moats that rise to heights of $30-40 \mathrm{~m}$ above the level of the abyssal plain and extend for 5-20 km. These features, together with the evidence of winnowing, indicate that bottom currents play an important role in sedimentation in this area.

Core and dredge data

A single dredge (PS2693-1) from the northeastern slope of Belgica Guyot $\left(65^{\circ} 18.3^{\prime} \mathrm{S} ; 90^{\circ} 35.2^{\prime} \mathrm{W}\right)$ recovered basaltic conglomerates and relatively unaltered fragments of basaltic lava flows from just below the rim of the guyot (water depths of 600-800 m). All rocks are coated with a black manganese crust. The conglomerate is monomictic and consists of well-rounded basaltic components, $1-5 \mathrm{~cm}$ in diameter. The basaltic pebbles are cemented by a fine-grained matrix containing a large fraction of volcanic sand. The conglomerate documents deposition in a high-energy beach or nearshore environment when the top of the guyot was at or above sea level.

The recovered fragments of basaltic lava flows are finegrained porphyric with dark gray to greenish color. Petrological and geochemical studies show that these samples are ocean island transitional to alkaline basalts generated by a low degree of partial melting (Hagedorn et al. 1997). K/Ar age measurements on the dredge samples yield Miocene ages between $20.1 \pm 1.0$ and $23.2 \pm 1.2 \mathrm{Ma}$.

Attempts to sample surface sediments on the summit of Belgica Guyot failed. Deployments of a gravity corer and a multicorer at site PS2689 $\left(65^{\circ} 27.8^{\prime} \mathrm{S} ; 90^{\circ} 32.7^{\prime} \mathrm{W}\right.$, water depth $417 \mathrm{~m}$ ) recovered only a small sample of sand and gravel. This supports the seismic and Parasound echosounder data that revealed no significant sediment cover on the summits of the guyots. Sediment samples were collected successfully in a sediment pocket on the western flank of Belgica Guyot (PS2690-1, 65 26.6'S; $90^{\circ} 47.8^{\prime} \mathrm{W}$, water depth $2404 \mathrm{~m}$ ) and at the base of the guyot (PS2691, 65 $23.7^{\prime} \mathrm{S} ; 91^{\circ} 10.3^{\prime} \mathrm{W}$, water depth $4715 \mathrm{~m}$, 
and PS2692, $65^{\circ} 08.3^{\prime} \mathrm{S} ; 90^{\circ} 41.0^{\prime} \mathrm{W}$, water depth $4674 \mathrm{~m}$ ) (Fig. 2).

The surface sediments at site PS2690 on the guyot flank are calcareous/diatomaceous mud, whereas the samples at sites PS2691 and PS2692 at the base of the guyot consist of diatomaceous mud. Gravity cores were collected at PS2691 and PS2692 with recovery of $2.71 \mathrm{~m}$ and $10.34 \mathrm{~m}$, respectively. Although diatoms are poorly preserved in these sediments, the occurrence of the diatoms Actinocyclus ingens and Fragilariopsis kerguelensis in the lower $3 \mathrm{~m}$ of core PS2692-4 indicates an age of $>0.6 \mathrm{Ma}$ for the lower portion of this core.

A $6.52-\mathrm{m}$ gravity core was collected at station PS2695 $\left(65^{\circ} 12.1^{\prime} \mathrm{S} ; 92^{\circ} 41.1^{\prime} \mathrm{W}\right.$, water depth $\left.3316 \mathrm{~m}\right)$ on the southwest flank of Lecointe Guyot. This core recovered diatombearing foraminiferal ooze from the Pleistocene Thalassiosira lentiginosa and Actinocyclus ingens diatom zones (Gersonde and Barcena 1997). A late Pleistocene average sedimentation rate of $0.5 \mathrm{~cm} / 1000 \mathrm{yr}$ was determined from this core.

\section{Discussion}

The De Gerlache Seamounts occur in an area of the remote SE Pacific that contains few other seamounts. The two guyots making up this group are the most southerly guyots yet known. They straddle a prominent $\mathrm{N}-\mathrm{S}$ gravity low that extends north from Peter I Island to about $62^{\circ} \mathrm{S}$ (Fig. 1). The structure of this gravity low is complex. In the area between the guyots, it actually consists of two lows, separated by an intervening ridge. These gravity lows are caused by basement ridges and sediment-filled grabens (Fig. 4). Another gravity lineation extends NNE from the Antarctic margin west of Peter I Island and appears to intersect the $\mathrm{N}-\mathrm{S}$ anomaly near the De Gerlache Seamounts. To add further complications to the tectonic setting of the guyots, they are also aligned with the Tharp Fracture Zone, part of the Eltanin Fracture Zone system originating at the Pacific-Antarctic Ridge. It is not clear if the Tharp Fracture Zone continues southeast of the De Gerlache Seamounts.

Bastien et al. (1976) published an age for basalts from Peter I Island of about $13 \mathrm{Ma}$, much younger than the surrounding oceanic crust (55-60 Ma). Other analyses of basaltic rocks from the island reveal evidence of volcanic activity until very recent times (Prestvik et al. 1990). The $\mathrm{K} / \mathrm{Ar}$ ages of 19-24 Ma for the De Gerlache Seamounts also indicate volcanic activity much younger than the surrounding crust (60-65 Ma).

The identification and interpretation of fragmentary magnetic anomaly patterns have revealed a complex tectonic history of the southern Pacific (Herron and Tucholke 1976; Cande et al. 1982; Mayes et al. 1990) that is not fully understood. The existence of a Phoenix (or Aluk) Plate that has been completely subducted beneath the Antarctic Peninsula since Cretaceous times is a well- established fact. However, several stage pole migrations of the Pacific-Antarctic spreading axis and major plate reorganizations in the southeast Pacific sector have been postulated (i.e., Stock and Molnar 1987; Mayes et al. 1990; Cande et al. 1995).

Seismic investigations and gravity modeling have been carried out to determine the origin of the unusual gravity anomalies in the vicinity of Peter I Island (Cunningham et al. 1994; Gohl et al. 1997a,b). The seismic and gravity data show evidence for a convergence event, at least in the south, including a subducted segment of crust and accreted sediment on the overlying plate. Gohl et al (1997a) suggest that this compressive event took place between 50 and $13 \mathrm{Ma}$, perhaps along an earlier transcurrent plate boundary that developed to accommodate relative motion between the Antarctic-Bellingshausen plate and the Phoenix plate.

It is possible that the De Gerlache Seamounts are genetically related to this structure that causes the gravity anomaly. Perhaps the intersection of this structure with the Tharp Fracture Zone weakened the crust enough to allow volcanism to form the guyots there. However, the geochemical similarity of the basalts dredged from Belgica Guyot to basalts of similar age from Peter I Island and areas of West Antarctica may indicate that the de Gerlache Seamounts formed from the mantle plume believed to be responsible for the Miocene volcanism in West Antarctica and that the proximity of the gravity anomaly is simply fortuitous.

\section{Conclusions}

The De Gerlache Seamounts actually consist of two guyots. Both are elliptical and about $90 \times 60 \mathrm{~km}$ at their bases. Belgica Guyot has a gently domed summit area that is about $17 \times 46 \mathrm{~km}$ and lies at depths between 390 and $600 \mathrm{~m}$. Lecointe Guyot has a more circular summit that is about $17 \mathrm{~km}$ in diameter and lies at depths between 350 and $500 \mathrm{~m}$. Multichannel seismic reflection and Parasound penetrating echosounder data show no evidence of significant sediment on the summits of these guyots. A dredge from just below the summit of Belgica Guyot recovered basaltic conglomerates, evidence of the highenergy beach or nearshore environment present when the summit of the guyot was at or near sea level. Relatively unaltered basalts recovered by the same dredge yielded $\mathrm{K} / \mathrm{Ar}$ ages between $20.1 \pm 1.0$ and $23.2 \pm 1.2 \mathrm{Ma}$.

The sea floor between and surrounding the guyots is generally flat and heavily sedimented. Elongate north-south basement ridges occur on the sea floor between the guyots. These ridges are associated with the gravity anomaly that extends between the guyots. The sediment-filled troughs between these ridges and the guyots contain up to $1.3 \mathrm{~km}$ of well-stratified, horizontally layered sediment. Parasound data show evidence of current winnowing in the sediments surrounding the guyots 
and reveal erosional moats on the north and west flanks of Belgica Guyot. Sediment cores collected on the flanks of the guyots recovered Pleistocene sediments with compositions and sedimentation rates similar to those from seamounts and ridges in the Atlantic and Indian sectors of the Southern Ocean (Gersonde et al. 1990).

The guyots straddle a prominent north-south gravity anomaly that extends north from the Antarctic margin. The origin of this anomaly is uncertain, but it is presently believed to be a relict transcurrent/compressional plate boundary. In the area of the De Gerlache Seamounts the anomaly is apparently caused by a block-faulted basement topography. It is possible that the seamounts formed because of this zone of crustal weakness, however, the question of how the De Gerlache Seamounts are related to this gravity anomaly remains uncertain.

Acknowledgments We thank Captain Allers and the crew of the Polarstern for their assistance in collecting the data presented here. P. Barker kindly provided bathymetric data from the JCR cruise. This is Contribution No. 1304 of the Alfred Wegener Institute for Polar and Marine Research, Bremerhaven.

\section{References}

Bastien TW, Lehmann EK, and Craddock C (1976) The geology of Peter I Island. In: Hollister CD, Craddock C, et al. (Eds.), Initial Reports Deep Sea Drilling Project. Washington, DC: US Government Printing Office 35:341-357

Cande SC, Herron EM, and Hall BR (1982) The early Cenozoic tectonic history of the southeast Pacific. Earth and Planetary Science Letters 57:63-74

Cande SC, Raymond CA, Stock J, and Haxby W (1995) Geophysics of the Pitman Fracture Zone and Pacific-Antarctic plate motions during the Cenozoic. Science 270:947-953

Cunningham AP, Larter RD, and Barker PF (1994) Glacially prograded sequences on the Bellingshausen Sea continental margin near $90^{\circ} \mathrm{W}$. Terra Antarctica 1:267-268

Gersonde R and Barcena MA (1997) Revision of the upper Pliocene-Pleistocene diatom biostratigraphy for the northern belt of the Southern Ocean. Micropaleontology, in press

Gersonde R, Abelmann A, Burckle LH, Hamilton N, Lazarus D, McCartney K, O'Brien B, Spiess V and Wise SW (1990)
Biostratigraphic synthesis of Neogene silicious microfossils from the Antarctic Ocean, ODP Leg 113 (Weddell Sea). In: Barker PF, Kennett JP, et al. (Eds.), Proceedings ODP, Pt. B. College Station, Texas: Ocean Drilling Program 113:915-936

Gohl K, Nitsche F, and Miller H (1997a) Seismic and gravity data reveal Tertiary interplate subduction in the Bellingshausen Sea, southeast Pacific. Geology 25:371-374

Gohl K, Nitsche F, Vanneste K, Miller H, Fechner N, Oszko L, Hübscher C, Weigelt E and Lambrecht A (1997b) Tectonic and sedimentary architecture of the Bellingshausen and Amundsen Sea Basins, SE Pacific, by seismic profiling. In: Ricci CA (Ed.), The Antarctic Region: Geological Evolution and Processes, in press

Grant JA and Schreiber R (1990) Modern swathe sounding and sub-bottom profiling technology for research applications: The Atlas Hydrosweep and Parasound systems. Marine Geophysical Researches 12:9-19

Hagedorn B, Gersonde R, Gohl K, and Hubberten H-W (1997) Petrology, geochemistry and $\mathrm{K} / \mathrm{Ar}$ age constraints of the eastern De Gerlache Seamount alkaline basalts (Southern Ocean, Pacific Sector). Marine Geology, in press

Herron EM and Tucholke BE (1976) Sea-floor magnetic patterns and basement structure in the southeastern Pacific. In: Hollister CD, Craddock C, et al. (Eds.), Initial Reports Deep Sea Drilling Project. Washington, DC: US Government Printing Office $35: 263-278$

Mammerickx J and Cande S (1982) General Bathymetric Chart of the Oceans (GEBCO) Sheet 5.15. Ottowa, Canada: Canadian Hydrographic Service

Mayes CL, Lawver LA and Sandwell DT (1990) Tectonic history and new isochron chart of the south Pacific. Journal of Geophysical Research 95:8543-8567

Prestvik T, Barnes CG, Sundvoll B and Duncan RA (1990) Petrology of Peter I y (Peter I Island), West Antarctica. Journal of Volcanology and Geothermal Research 44:315-338

Smith WHF and Sandwell DT (1994) Bathymetric prediction from dense satellite altimetry and sparse shipboard bathymetry. Journal of Geophysical Research 99:21803-21824

Stock J and Molnar P (1987) Revised history of early Tertiary plate motion in the south-west Pacific. Nature 325:495-499

Tucholke BE and Houtz RE (1976) Sedimentary framework of the Bellingshausen Basin from seismic profiler data. In: Hollister CD, Craddock C, et al. (Eds.), Initial Reports Deep Sea Drilling Project. Washington, DC: US Government Printing Office $35: 197-227$

Vogt PR and Smoot NC (1984) The Geisha Guyots: Multibeam bathymetry and morphometric interpretation. Journal of Geophysical Research 89:11085-11187 